\title{
Az allogén vérképző őssejtátültetés korai szövődményei gyermekkorban
}

\author{
Horváth Orsolya ${ }^{1} @$, Nyirő Judit ${ }^{1}$, Kállay Krisztián ${ }^{1}$, Mező Blanka ${ }^{2}$, Kassa Csaba ${ }^{1}$, Hau Lídia ${ }^{1}$, \\ Kertész Gabriella ${ }^{1}$, Horváth Máté ${ }^{1}$, Sinkó János ${ }^{3}$, Prohászka Zoltán ${ }^{2}$, Kriván Gergely ${ }^{1}$ \\ ${ }^{1}$ Dél-pesti Centrumkórház, Országos Hematológiai és Infektológiai Intézet, \\ Gyermekhematológiai és Őssejt-transzplantációs Osztály, Budapest \\ ${ }^{2}$ Semmelweis Egyetem, Belgyógyászati és Hematológiai Klinika, Budapest \\ ${ }^{3}$ Dél-pesti Centrumkórház, Országos Hematológiai és Infektológiai Intézet, \\ Hematológiai és Őssejt-transzplantációs Osztály, Budapest
}

\begin{abstract}
Bevezetés: Az allogén vérképző őssejt-transzplantáció (tx) indikációja gyermekkorban a magas szövődményráta és a nem elhanyagolható halálozás miatt csak az életet veszélyeztető betegségekre korlátozódik. A csökkentett toxicitású kondícionáló kezelések bevezetése után célul tüztük ki az egyes a transzplantációs szövődmények, mint graft-versushost betegség (GVHD), vírusreaktiváció és transzplantációhoz társult thromboticus microangiopathia (TA-TMA) időbeli és egymáshoz viszonyított előfordulásának és a különböző kondícionáló kezelések és a fenti transzplantációs szövődmények összefüggéseinek feltárását. Betegek és módszer: Prospektíven száz $(8,5 \pm 4,9$ év) gyermeket vizsgáltunk, akik malignus $(n=54)$ és nem malignus alapbetegség $(n=46)$ miatt részesültek allogén tx-ban. A kondícionáló kezelés megkezdésétől monitoroztuk a korai szövődmények, így az akut GVHD, a vírusreaktivációk, a TA-TMA felléptét, illetve relapszus jelentkezését. Eredmények: A gyerekek kétharmadánál (67\%) észleltünk legalább egy korai szövődményt a felsoroltak közül. A leggyakoribb transzplantációs szövődmény a vírusreaktiváció volt (50\%). Akut GVHD a betegek 26\%-ánál, a medián 31. (10.-174.) napon alakult ki. Az akut GVHD-s esetek 27\%-a (7/26) zajlott súlyos (Grade III-IV) formában. A TA-TMA döntően enyhe volt, kizárólag ciclosporin adása során, más transzplantációs szövődményekhez társultan jelentkezett. A TA-TMA kialakulását 5/20 esetben GVHD, 5/20 esetben vírusreaktiváció, és 4/20 esetben vírusreaktiváció és GVHD is megelőzte. A súlyos szövődmények alacsony számával ellentétben a relapszusráta $(22 / 54 ; 41 \%)$ magas volt. A vizsgált betegcsoport összesített túlélése medián 3,8 $(1,3-6,5)$ év követési idő múltán 74\%. A nem malignus betegség miatt transzplantált gyermekek összesített túlélése kiváló (43/46; 93,5\%). Ezzel szemben a malignus csoportban a halálozási arány - a magas relapszusrátának megfelelően - (17/54, 31,5\%) magas. Következtetés: A csökkentett toxicitású kondícionáló kezelések bevezetése óta a súlyos korai transzplantációs szövődmények száma alacsony. A TA-TMA döntően enyhe formában, vírusreaktivációhoz vagy GVHD-hoz társultan jelentkezett. A malignus alapbetegség esetén a halálozás fő oka a relapszusok magas száma.
\end{abstract}

Kulcsszavak: vérképző őssejt-transzplantáció, szövődmény, thromboticus microangiopathia

\section{Early complications after allogeneic stem cell transplantation in childhood}

Introduction: Pediatric allogeneic hematopoietic stem cell transplantation (HSCT) is associated with severe treatment-related complications, including mortality. Therefore, HSCT remains a therapeutic option for patients with life-threatening medical conditions. After the introduction of reduced toxicity conditioning regimen, we aimed to identify the interrelation and the time to development of early transplant-related complications, as graft-versus-host disease (GVHD), viral reactivations and transplantation-associated thrombotic microangiopathy (TA-TMA). At the same time we also aimed to analyze the role of different conditioning therapies in the development of these complications. Patients and methods: Hundred pediatric (age $8.5 \pm 4.9 \mathrm{yrs}$ ) patients, treated with HSCT for malignant $(N=54)$ and non-malignant $(N=46)$ indications, have been enrolled in this prospective study. From the start of conditioning therapy, early transplant-related comlications, as acute GVHD, viral reactivations, and TA-TMA and the occurrence of relapse were monitored. Results: Two third of the patients (67\%) developed at least one of the monitored early complications. The most frequent HSCT complication was viral reactivation (50\%). Acute GVHD occurred in $26 \%$ of patients, on median day $31(10-174) .27 \%$ of the acute GVHD cases $(7 / 26)$ were graded as severe (Grade III-IV). In the

\footnotetext{
${ }^{\circledR}$ Levelezési cím: Dr. Horváth Orsolya, Dél-pesti Centrumkórház, Országos Hematológiai és Infektológiai Intézet, Gyermekhematológiai és Őssejt-transzplantációs Osztály, 1097 Budapest, Albert Flórián út 5-7. 11/4A; Tel.: +36-30-502-5654, E-mail: orsolyahorvath.mail@gmail.com
} 
majority of patients, TA-TMA remained mild, self-limiting, without any sign of organ damage, and occurred only during ciclosporin immunosuppression. TA-TMA was preceded by acute GVHD in 5 in 20, by viral reactivation in 5 in 20 , or by both in 4 in 20 cases. In contrast to the low incidence of early HSCT-related complications, relapse rate $(22 / 54 ; 41 \%)$ was high. Overall survival after a median 3.8 (1.3-6.5) year follow-up time was $74 \%$. Overall survival was excellent $(43 / 46 ; 93.5 \%)$ in non-malignant patients. On the contrary, in patients with malignant diseases, mortality rate $(17 / 54,31.5 \%)$ was high due to high relapse rate. Conclusions: Since the introduction of reduced toxicity conditioning regimen, the rate of severe HSCT-related complications is low. TA-TMA occurred typically in a mild form after GVHD and/or viral infection or reactivation. In patients with malignant conditions, mortality was driven by high relapse rate.

Keywords: hematopoietic stem cell transplantation, thrombotic microangiopathies, complement activation

(Beérkezett: 2020. július 23.; elfogadva: 2020. szeptember 8.)

\section{Rövidítések}

ASBMT - Amerikai Csontvelő-transzplantációs Társaság (American Society of Blood and Marrow Transplantation); CMV - cytomegalovírus; EBV - Epstein-Barr-vírus; GVHD graft-versus-host betegség; IWG - Nemzetközi Munkacsoport (International Working Group); LDH - Laktát-dehidrogenáz; NS - nem szignifikáns; O-TMA - összesített thromboticus microangiopathia csoportosítás (Overall Thrombotic Microangiopathy Grouping); sC5b-9 - szolúbilis terminális út aktivációs komplex; TA-TMA - őssejt-transzplantációhoz társult thromboticus microangiopathia; tx - őssejt-transzplantáció; UPN egyedi betegazonosító szám (unique patient number)

\section{Bevezetés}

Gyermekkorban az allogén vérképző őssejtátültetés számos malignus betegségben, veleszületett vagy szerzett hematológiai kórképben, anyagcsere betegségben és immunhiányos állapotban jelent kezelési lehetőséget [1-3]. A potenciálisan kuratív betegségspektrum ellenére, a magas szövődményráta és a nem elhanyagolható halálozás miatt indikációja ebben a korcsoportban csak az életet veszélyeztető betegségekre korlátozódik [3]. Az őssejttranszplantáció (tx) kimenetelét és sikerét elsősorban a transzplantációhoz kötődő morbiditás és mortalitás mértéke, valamint malignitás esetén a relapszusráta határozzák meg [4].

A szekunder immundeficiencia és az immunszuppreszszió miatt a beavatkozás egyik leggyakoribb szövődménye a vírusreaktiváció [5]. Az akut graft-versus-host betegség (GVHD) gyakoriságát és súlyosságát többek közt a transzplantáció és a graft típusa befolyásolja [6]. A súlyos GVHD (Grade III-IV, viscerális és/vagy többszervi érintettség) az immunszuppresszív terápiák fejlődése ellenére nagyban felelős a transzplantációhoz társuló halálozásért [6].

Az őssejt-transzplantációhoz társult thromboticus microangiopathia (TA-TMA) egy újonnan definiált, komplement aktivációval járó, multifaktoriális eredetű szövődmény. Incidenciáját tekintve, a különböző diagnosztikus kritériumrendszerek miatt nagyon eltérő értékeket (0,5\%-63,6\%) találunk az irodalomban [7]. A nagy szórást mutató gyakoriság hátterében a kondícionáló kezelésekben bekövetkezett változások és a szövettani mintavétel- ből adódó nehézségek is állhatnak [7]. A TA-TMA diagnózisát tovább nehezítette, hogy korábban használt diagnosztikus kritériumrendszerek olyan hematológiai és vesekárosodást jelző klinikai paramétereket vesznek alapul, melyek már egy zajló, szervkárosodással járó folyamatot jeleznek [8-10]. A diagnosztikus kritériumok legfrissebb módosítása azonban a komplement aktivációs markerek vizsgálatával, valamint a magas vérnyomás és proteinuria figyelembevételével, a kialakuló TA-TMA korábbi klinikai diagnózisát teszik lehetővé [11]. Korábban közreadott vizsgálati eredményeink is megerősítették a komplement aktivációs marker szerepének jelentóségét a TA-TMA kialakulásában [12].

A szövődmények korai felismerése és adekvát kezelése a sikeres allogén őssejtátültetés sarkalatos pontja. Gyermekkorban az eljárás gyakorlata ráadásul nagyban különbözik a felnőttkorban alkalmazottól, melynek hátterében főként a nem malignus betegségek elérő klinikai megközelítése és a graft-versus-host betegség kisebb gyakorisága állnak [13].

Vizsgálatunk céljául a transzplantációs szövődmények, mint GVHD, vírusreaktiváció és TA-TMA időbeli és egymáshoz viszonyított előfordulásának, és a különböző kondícionáló kezelések és a fenti transzplantációs szövődmények összefüggéseinek feltárását tűztük ki. Jelen célkitúzéseink meghatározásához a gyermekkori kondícionáló kezelések toxicitásában és a TA-TMA új diagnosztikus kritériumaiban bekövetkezett változásokat vettük alapul.

\section{Betegek és módszer}

\section{Betegek, minta- és adatgyüjtés}

Százhuszonnégy gyermek részesült allogén vérképző őssejt-transzplantációban 2013 novembere és 2019 februárja között a Dél-pesti Centrumkórház (korábban Egyesített Szent István és Szent László Kórház) Gyermekhematológiai és Össejt-transzplantációs Osztályán. A prospektív, konszekutív kohorsz vizsgálat beválasztási kritériumainak 100 gyermek felelt meg. Esetükben további adatgyüjtést és komplement méréseket végeztünk. 
A transzplantáció 54/100 esetben malignus és 46/100 esetben nem malignus betegség miatt történt. A kizárási kritériumok a $10 \mathrm{~kg}$ alatti testtömeg (12 beteg), a korai, $<30$ nappal tx-en belüli halálozás ( 3 beteg) és a komplement méréshez történt mintavételi technikai hiba ( 7 beteg) voltak. Ha egy gyermeknek (2 beteg) a vizsgálati időszak alatt két transzplantációja is történt, akkor az első transzplantáció eredményeivel számoltunk. A 10 kg alatti gyermekek a komplement mérésekhez szükséges mintavételi nehézség miatt kerültek kizárásra. A transzplantációs szövődmények és túlélési eredmények változásának összehasonlításához a 2008 januárja és 2013 októbere között allogén transzplantációban részesült gyermekek eredményeinek adataiból historikus betegcsoportot $(n=$ 54) képeztünk. Az adatgyüjtést az Európai Csontvelötranszplantációs Társaság adatbázisának segítségével végeztük.

\section{Laboratóriumi és klinikai paraméterek meghatározása}

A transzplantáció előre meghatározott időpontjaiban (a kondícionáló kezelés előtt, és a $+28,+56$. és +100 . tx utáni napokon) mértük a szolúbilis terminális komplement aktivációs komplex (sC5b-9) szintjét a TA-TMA diagnózisához. A mintagyüjtés a Helsinki Deklaráció elveinek megfelelően, tájékozott szülői beleegyezést követően történt, vizsgálatunkat az Egészségügyi Tudományos Tanács Tudományos és Kutatásetikai Bizottságának jóváhagyásával végeztük.

A TA-TMA aktivitását az alábbi paraméterek változásaival monitorizáltuk: anaemia, thrombocytopenia, Coombsteszt, laktát-dehidrogenázszint ( $\mathrm{LDH})$, kreatinin- és haptoglobinszintek, fragmentocyták száma (vérkép automatával meghatározva), magas vérnyomás, illetve proteinuria megléte.

A graft megtapadását akkor regisztráltuk, ha az abszolút neutrofilszám három egymást követő napon meghaladta a 0,5 G/L-t, melyből az első nap a megtapadás napja.

\section{Az össejt-transzplantáció utáni szövődmények definíciója}

A graft-versus-host betegség (GVHD) mértékét a Glucksberg-kritériumok segítségével határoztuk meg [14]. Az aciklovir profilaxist a kondícionáló kezelés első napján kezdtük meg. A vírusreaktivációkat hetente polimeráz láncreakcióval (PCR) monitoroztuk (Epstein-Bar-vírus, cytomegalovírus, adenovírus). Vírusreaktivációnak tekintettük, ha klinikailag szignifikáns kópiaszámemelkedést $(>1000 \mathrm{IU} / \mathrm{ml}$ ) detektáltunk. Preemptív terápiaként rituximabot, foscarnetet, ganciklovirt vagy cidofovirt alkalmaztunk. Öt különböző TA-TMA diagnosztikus kritériumrendszer alapján soroltuk be a betegeinket: 1) a Nemzetközi Munkacsoport klinikai kritériumai (IWG) [8], illetve 2) az Amerikai Csontvelő-transzplantációs
Társaság (ASBMT) [9], 3) Cho és mtsai [10], 4) City of Hope [15], valamint 5) Jodele és mtsai diagnosztikus kritériumai [11] alapján. A TA-TMA diagnózisának időpontjaként azt a transzplantáció utáni napot vettük figyelembe, amikor Jodele és mtsai diagnosztikus kritériumait a betegek teljesítették. A historikus betegcsoportban a TATMA követésére a komplement aktivitás monitorizálásával még nem volt lehetőség.

\section{Statisztikai módszerek}

A legtöbb változó nem követte a normál eloszlást, ezért nem paraméteres teszteket használtunk a csoportok öszszehasonlítására. Az eseménymentes túlélések becsléséhez a Kaplan-Meier-módszert alkalmaztuk, és log-rank teszttel hasonlítottuk össze a túlélési görbéket. Kétoldalas $p$ értékeket számoltunk, és az eredményt 0,05 alatt tekintettük szignifikánsnak $(p<0,05)$. A számításokat a Statistica 8.0 és a GraphPad Prism 6.03 statisztikai szoftverek segítségével végeztük.

\section{Eredmények}

\section{Demográfiai eredmények}

Prospektíven száz $(8,5 \pm$ 4,9 év) gyermeket vizsgáltunk, akik malignus ( $n=54$ ) és nem malignus alapbetegségük $(n=46)$ miatt részesültek allogén tx-ban. Myeloablatív kondícionáló kezelést a betegek $68 \%$-ánál, csökkentett intenzitású kondícionáló kezelést a betegek 32\%-ánál alkalmaztunk. A betegek többsége (52\%) treosulfan alapú kondícionáló kezelésben részesült. Busulphan alapú kondícionáló kezelést a betegek $21 \%$-a kapott, teljestest besugárzást a vizsgálati idő alatt nem alkalmaztunk. A betegek 27\%-a egyéb, csökkentett intenzitású kondícionáló kezelésben részesült. A betegek többsége idegen donortól származó humán leukocyta antigén-identikus (70\%) csontvelői graftot (72\%) kapott. A gyermek betegcsoportunkban sem haploidentikus, sem identikus transzplantáció esetén nem alkalmaztunk poszt-transzplantációs cyclophosphamid kezelést tartalmazó protokollt. A betegcsoport részletesebb demográfiai adatait és klinikai jellemzőit az 1. táblázat mutatja be.

\section{Transzplantációs szövödmények}

A gyerekek kétharmadánál (67\%) észleltünk legalább egy korai szövődményt a GVHD, primer CMV, EBV vagy adenovírus-infekció vagy vírusreaktiváció, illetve TATMA közül. A leggyakoribb transzplantációs szövődmény a vírusreaktiváció volt (50\%) betegcsoportunkban. Egy-egy betegnél primer cytomegalovírus, illetve primer Epstein-Barr-vírusfertőzést észleltünk. Az értékelés során a vírusreaktivációkat és a primer infekciókat egy csoportként kezeltük $(N=52)$, így vírusreaktiváció vagy primer infekció a medián 33. napon (2-223. nap) jelentke- 
1. táblázat. Demográfiai, kezelési, túlélési adatok és a transzplantáció korai szövődményei

\begin{tabular}{|c|c|c|c|}
\hline & $\begin{array}{l}\text { TA-TMA-s betegek } \\
\qquad(n=20)\end{array}$ & $\begin{array}{l}\text { Nem TA-TMA-s betegek } \\
\qquad(n=80)\end{array}$ & $p$ \\
\hline Életkor (év, medián) & $8,3(1,8-14,9)$ & $8,4(0,5-19,5)$ & 0,25 \\
\hline Fiú/Lány & $14 / 6$ & $45 / 35$ & 0,26 \\
\hline \multicolumn{4}{|l|}{ A transzplantáció indikációja } \\
\hline Malignitás & $10(50 \%)$ & $44(55 \%)$ & 0,68 \\
\hline Csontvelő elégtelenség & $8(40 \%)$ & $25(31 \%)$ & 0,45 \\
\hline Egyéb (immundeficiencia vagy metabolikus betegség) & $2(10 \%)$ & $11(14 \%)$ & 0,65 \\
\hline \multicolumn{4}{|l|}{ Korábbi transzplantációk száma } \\
\hline 0 & $18(90 \%)$ & $73(91 \%)$ & \multirow{3}{*}{0,86} \\
\hline 1 & $1(5 \%)$ & $7(9 \%)$ & \\
\hline 2 & $1(5 \%)$ & $0(0 \%)$ & \\
\hline \multicolumn{4}{|l|}{ Donor típusa } \\
\hline Identikus rokon & $5(25 \%)$ & $18(22,5 \%)$ & \multirow{3}{*}{ NS } \\
\hline Haploidentikus rokon & $1(5 \%)$ & $6(7,5 \%)$ & \\
\hline Idegen donor & $14(70 \%)$ & $56(70 \%)$ & \\
\hline \multicolumn{4}{|l|}{ Össejtforrás } \\
\hline Csontvelö & $14(70 \%)$ & $58(72 \%)$ & \multirow{3}{*}{0,82} \\
\hline Perifériás vér & $5(25 \%)$ & $15(19 \%)$ & \\
\hline Köldökvér & $1(5 \%)$ & $7(9 \%)$ & \\
\hline \multicolumn{4}{|l|}{ Kondícionáló kezelés } \\
\hline Csökkentett intenzitású & $5(25 \%)$ & $27(34 \%)$ & \multirow{2}{*}{0,45} \\
\hline Myeloablatív & $15(75 \%)$ & $53(66 \%)$ & \\
\hline Busulphan alapú & $3(15 \%)$ & $18(22,5 \%)$ & 0,46 \\
\hline Treosulfan alapú & $13(65 \%)$ & $39(49 \%)$ & 0,19 \\
\hline \multicolumn{4}{|l|}{ Megtapadás } \\
\hline Megtapadás (nap) & $18(13-26)$ & $21(9-50)$ & 0,82 \\
\hline \multicolumn{4}{|l|}{ Transzplantációhoz társuló szövődmények } \\
\hline Akut GVHD & $12(60 \%)$ & $14(17,5 \%)$ & $0,0001^{*}$ \\
\hline Vírusinfekció/ reaktiváció & $13(65 \%)$ & $39(49 \%)$ & 0,19 \\
\hline GVHD vagy vírus reaktiváció & $18(90 \%)$ & $47(59 \%)$ & $0,0088^{*}$ \\
\hline GVHD és vírus reaktiváció & $7(35 \%)$ & $6(7,5 \%)$ & $0,0011^{*}$ \\
\hline Relapszus malignitás esetén & $3 / 10(30 \%)$ & $19 / 44(43 \%)$ & 0,44 \\
\hline Relapszus miatti halálozás & $2 / 10(20 \%)$ & $15 / 44(34 \%)$ & 0,92 \\
\hline Transzplantációval összefüggő halálozás & $3(15 \%)$ & $6(7,5 \%)$ & 0.520 \\
\hline Összesített túlélés & $15(75 \%)$ & $59(74 \%)$ & 0,90 \\
\hline
\end{tabular}

GVHD - graft-versus-host betegség; TA-TMA - transzplantációhoz társult thromboticus microangiopathia

zett. A vírusreaktivációk közül 36 esetben cytomegalovírus, 12 esetben Epstein-Barr-vírus, 14 esetben adenovírus-reaktivációt észleltünk. Két vírus együttes reaktivációja 9 betegnél jelentkezett (EBV és adenovirus: 3, CMV és EBV: 6).

Akut GVHD a betegek 26\%-ánál, medián a 31. napon (10-174. nap) alakult ki. Ez az esetek 27\%-ában (7/26) súlyos formában zajlott (Grade III-IV). Két késői megjelenésű (107. és 174. nap) akut GVHD őssejtbooster és human herpeszvírus 6 vírusreaktiváció után jelentkezett.
Nem volt szignifikáns különbség a vírusreaktiváció és akut GVHD előfordulásában a különböző kondícionáló kezelést kapó csoportok között.

\section{A TA-TMA elöfordulása}

A szövődmények közül érdeklődésünk leginkább az újonnan definiált transzplantációs szövődmény, a TA-TMA jellemzésére irányult. Összesen 20/100 betegnél definiál- 
2. táblázat. Az őssejt-transzplantációhoz társult thromboticus microangiopathia kritériumrendszereinek teljesülése betegcsoportunkban

\begin{tabular}{lcc}
\hline & Incidencia\% $(N)$ & $\begin{array}{c}\text { Diagnózis időpontja } \\
\text { (medián (min-max)) }\end{array}$ \\
\hline IWG kritériumai [8] & $12 \%(12 / 100)$ & $44(16-90)$ \\
ASBMT kritériumai [9] & $8 \%(8 / 100)$ & $35,5(12-83)$ \\
O-TMA kritériumai [10] & $12 \%(12 / 100)$ & $44(16-90)$ \\
City of Hope kritériumok [15] & $10 \%(10 / 100)$ & $57,5(16-85)$ \\
Jodele és mtsai kritériumai [11] & $20 \%(20 / 100)$ & $50(16-98)$ \\
\hline
\end{tabular}

A diagnózisnál a napok a transzplantáció óta eltelt napok számát jelzik.

ASBMT - Amerikai Csontvelő-transzplantációs Társaság; IWG - Nemzetközi Munkacsoport;

O-TMA - összesített thromboticus microangiopathia csoportosítás

tunk az enyhétől a súlyos esetekig terjedő TA-TMA-t. A kritériumok alapján meghatározott előfordulási arányt a 2. táblázat mutatja. A TA-TMA incidenciáját és a diagnózis időpontját befolyásolja az alkalmazott diagnosztikus kritériumrendszer. A transzplantációs szövődmények összehasonlításánál a legérzékenyebb kritériumrendszert szerettük volna alkalmazni, ezért az összehasonlításnak a TA-TMA-t az enyhe eseteket is magában foglaló definíció, Jodele és mtsai diagnosztikus kritériumai alapján definiáltuk [11]. Minden beteg, aki bármely másik kritériumrendszer alapján TA-TMA betegcsoportba tartozott, teljesítette a Jodele féle kritériumokat is. E kritériumok alapján a TA-TMA medián az 50. napon (1-98, min-max) jelentkezett. A TA-TMA-s betegek körében a malignus $(N=10)$ és nem malignus $(N=10)$ indikáció miatt végzett allogén vérképző őssejt-transzplantáció egyenlő arányban fordult elö.

A sC5b-9 szint - a komplementaktiváció markereként - valamennyi (20/20) TA-TMA epizód esetén a transzplantáció előtti kiindulási szinthez képest megemelkedett a +28. napra. Bár minden TA-TMA-s esetben tapasztaltunk a kezdeti sC5b-9 szinthez képest emelkedést, ennek ellenére 5/20 TA-TMA-a esetben sC5b-9 szintje normál tartományban maradt $(<250 \mathrm{ng} / \mathrm{ml})$. A csökkentett toxicitású kondícionáló kezelés után a betegek nagy részénél a TA-TMA enyhe, önkorlátozó formában zajlott, szervkárosodásra utaló jelek nélkül. A calcineurin inhibitorok elhagyása vagy váltása után a betegek nagy részénél (18/20 esetben) a TA-TMA oldódott. Egy beteg (UPN39) defibrotide kezelésben részesült. Eculizumabkezelést a vizsgálatba kerülö betegek nem kaptak.

A TA-TMA busulphan alapú kondícionáló kezelés után 3/21, treosulfan alapú kapcsán 13/52 esetben, egyéb kondícionáló kezelés után 4/27 esetben jelentkezett. A vizsgált betegcsoporban a különböző kondícionáló kezelést kapó betegcsoportok között nem volt szignifikáns különbség a TA-TMA előfordulásában.

Minden TA-TMA epizód ciclosporin adása során jelentkezett (20/85), nem észleltünk TA-TMA-t tacrolimus $(0 / 11)$ és mycophemolat mofetil $(0 / 3)$ immunszuppresz-

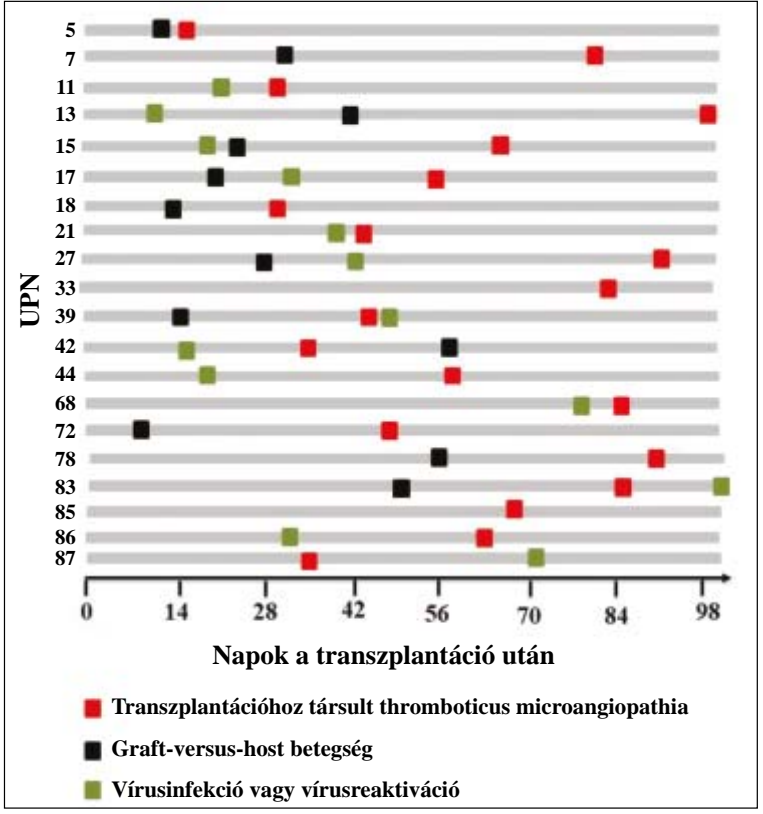

1. ábra. A transzplantációs szövődmények egymáshoz viszonyított időbeli előfordulása a TA-TMA-s betegekben. UPN - egyedi betegazonosító szám (unique patient number) 
szió során. Egy gyermek szingén (egypetéjű ikertestvér-donoros) transzplantációja után nem részesült immunszuppresszív kezelésben.

\section{Transzplantációs szövődmények összefüggései}

A következő lépésben a TA-TMA időbeli előfordulását vizsgáltuk a többi transzplantációs szövődményhez viszonyítva. Jellemzően a TA-TMA graft-versus-host betegség és/vagy vírusreaktiváció után jelentkezett. A TA-TMA kialakulását 5/20 esetben GVHD, 5/20 esetben vírusreaktiváció, és 4/20 esetben vírusreaktiváció és GVHD is megelőzte. A betegcsoportban csak $2 / 20$ olyan TATMA-s beteg volt, akiknél nem jelentkezett GVHD és/ vagy vírusreaktiváció korai szövődményként. Az egyik beteg malignus alapbetegsége a TA-TMA diagnózisával egy időben recidívált. Az 1. ábra a TA-TMA-s betegekben a transzplantációs szövődmények egymáshoz viszonyított időbeli előfordulását ábrázolja.

TA-TMA-s betegekben gyakrabban fordult elő GVHD $(12 / 20$ vs. $14 / 80 ; p=0,0001)$, illetve GVHD és vírusinfekció vagy -reaktiváció együttesen $(7 / 20$ vs $6 / 80, p=$ $0,0011)$. Malignitás esetén a TA-TMA-s betegek körében nem volt gyakoribb a relapszus aránya $(3 / 10(30 \%)$ vs. 19/44 (43\%); $p=0,44)$.

\section{Relapszusráta}

A korai transzplantációs szövődmények mellett az egy éven belüli recidíva aránya volt jelentős a vizsgált betegek körében. Malignus alapbetegség esetén a relapszusráta $(22 / 54 ; 41 \%)$ magas volt. Nem volt különbség a relapszusrátában a treosulfan vagy busulphan alapú kondícionáló kezelés után $(45,5 \%(15 / 33)$ vs. $39 \%(7 / 18) ; p=$ $0,65)$. A betegek nagy része $(19 / 22)$ a transzplantáció utáni első évben recidívált. A recidívia kumulatív incidenciáját a 2. ábra mutatja.

\section{Historikus betegcsoport}

A korai transzplantációs szövődmények és relapszus adatok összehasonlításához a 2008. január 1. és 2013. október 31. között allogén transzplantációban részesült gyerekek adataiból historikus betegcsoportot képeztünk (3. táblá$z a t)$. A historikus betegcsoportban a betegek döntő többsége myeloablatív (83\%), busulphan (54\%) vagy teljestest-besugárzás (11\%) alapú kondícionáló kezelésen esett át. A historikus betegcsoportban szignifikánsan magasabb volt az akut GVHD (26/100 vs. $24 / 54 ; p=0,02)$, és kimagaslóan magas volt a súlyos Grade III-IV GVHD (7/100 vs. $10 / 54 ; p=0,03)$ aránya. A vírusinfekciók/-reaktivációk számában nem volt különbség (52/100 vs. 21/54; $p=0,16)$ a két csoport között.

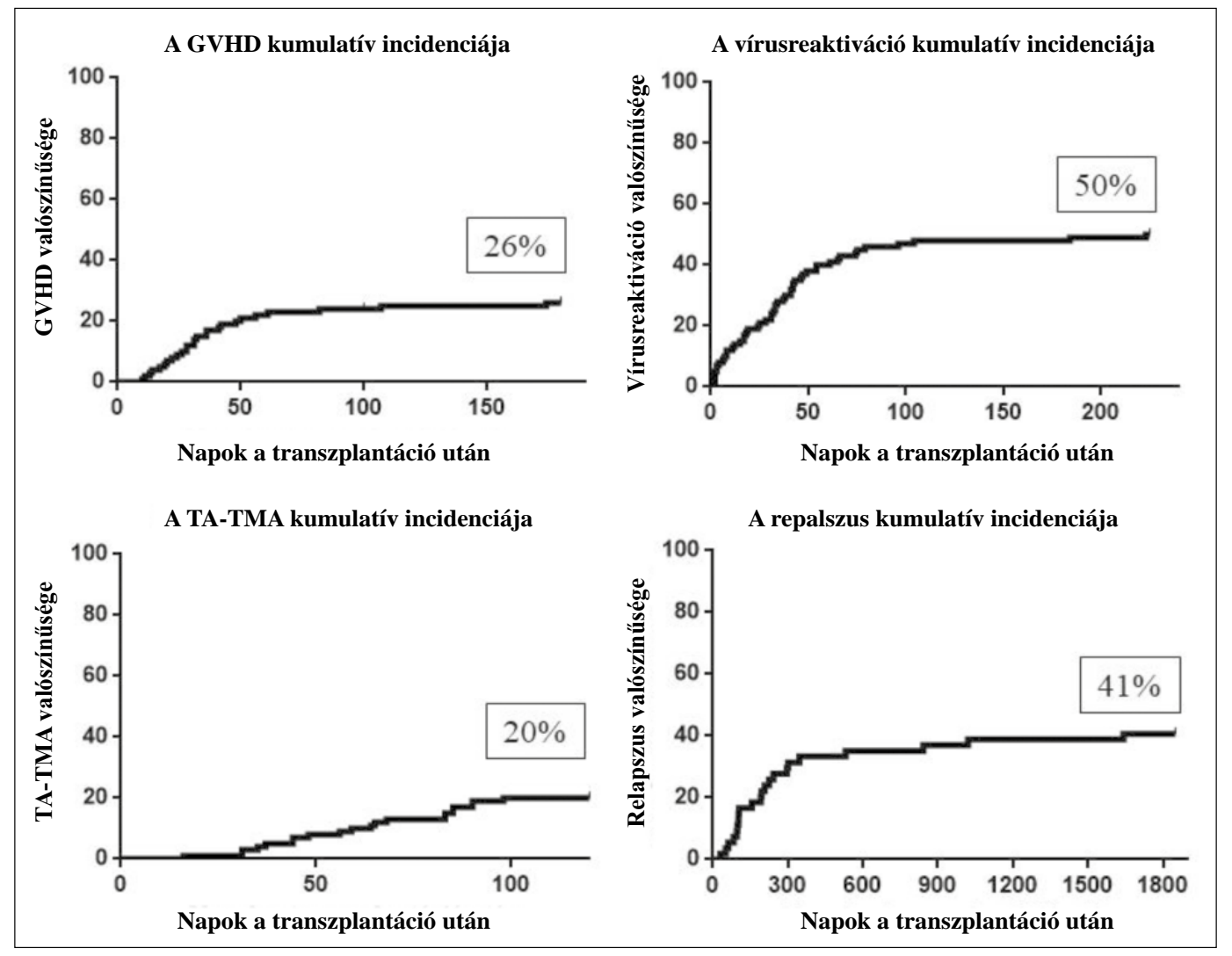

2. ábra. A graft-versus-host betegség, vírusreaktiváció, transzplantációhoz társult thrombotikus microangiopathia és a relapszus kumulatív incidenciája betegcsoportunkban. GVHD - graft-versus-host betegség; TA-TMA - transzplantációhoz társult thromboticus microangiopathia); $x$ tengely: napok a transzplantáció után; $y$ tengely: a kumulatív incidenciák 
3. táblázat. A transzplantációs adatok, korai transzplantációhoz társuló szövődmények és túlélési adatok összehasonlítása a saját historikus kontrollcsoporttal

\begin{tabular}{|c|c|c|c|}
\hline & $\begin{array}{c}\text { Betegcsoport } \\
2013-2019\end{array}$ & $\begin{array}{c}\text { Betegcsoport } \\
2008-2013\end{array}$ & $p$ \\
\hline Fiú/Lány & $59 / 41$ & $37 / 17$ & 0,24 \\
\hline Malignus/Nem malignus & $54 / 46$ & $31 / 23$ & 0,68 \\
\hline Myeloablatív kondícionálás & $68 / 100(68 \%)$ & $45 / 54(83 \%)$ & $0,039^{*}$ \\
\hline Busulphan alapú kondícionálás & $21 / 100(21 \%)$ & $29 / 54(54 \%)$ & $<0,0001^{*}$ \\
\hline Treosulfan alapú kondícionálás & $52 / 100(52 \%)$ & $9 / 54(17 \%)$ & $<0,0001^{*}$ \\
\hline Teljestest-besugárzás & $0 / 100(0 \%)$ & $6 / 54(11 \%)$ & - \\
\hline Csontvelői graft & $72 / 100(72 \%)$ & $19 / 54(35 \%)$ & $<0,0001^{*}$ \\
\hline Perifériás vérből nyert graft & $20 / 100(20 \%)$ & $18 / 54(33,5 \%)$ & 0,06 \\
\hline Köldökvér & $8 / 100(8 \%)$ & $17 / 54(31,5 \%)$ & $0,0002^{*}$ \\
\hline Idegen donor & $70 / 100(70 \%)$ & $43 / 54(80 \%)$ & 0,19 \\
\hline Identikus rokon donor & $23 / 100(23 \%)$ & $9 / 54(17 \%)$ & 0,35 \\
\hline Haploidentikus rokon donor & $7 / 100(7 \%)$ & $2 / 54(3 \%)$ & 0,40 \\
\hline Akut graft-versus-host betegség & $26 / 100(26 \%)$ & $24 / 54(44 \%)$ & $0,02^{*}$ \\
\hline Grade III-IV GVHD & $7 / 100(7 \%)$ & $10 / 54(19 \%)$ & $0,03^{*}$ \\
\hline Vírusinfekció/-reaktiváció & $52 / 100(52 \%)$ & $21 / 54(39 \%)$ & 0,11 \\
\hline GVHD vagy vírusreaktiváció & $65 / 100(65 \%)$ & $23 / 54(43 \%)$ & $0,007^{*}$ \\
\hline GVHD és vírusreaktiváció & $13 / 100(13 \%)$ & $11 / 54(20 \%)$ & 0,22 \\
\hline Relapszus malignitás esetén & $22 / 54(41 \%)$ & $10 / 31(32 \%)$ & 0,43 \\
\hline Relapszus miatti halálozás & $17 / 54(31 \%)$ & $9 / 31(29 \%)$ & 0,81 \\
\hline Transzplantációval összefüggő halálozás & $9 / 100(9 \%)$ & $22 / 54(41 \%)$ & $<0,00001^{*}$ \\
\hline Összesített túlélés & $74 / 100(74 \%)$ & $23 / 54(43 \%)$ & $0,0001^{*}$ \\
\hline
\end{tabular}

GVHD - graft-versus-host betegség

\section{Betegek túlélése}

Az összesített túlélés medián 3,8 év (1,3-6,5 év; minmax) követési idő múlva $74 \%$ volt. Nem malignus alapbetegség esetén az összesített túlélés kiváló (43/46; 93,5\%). Ezzel szemben malignitásban szenvedőknél a relapszusráta $(22 / 54 ; 41 \%)$ és a relapszushoz kötődő halálozás (17/54, 31,5\%) magas. Ebben a csoportban 17/23 beteg halt meg relapszusban, míg 6/23 esetben a halál oka transzplantációval összefüggő szövődmény volt. Ennek megfelelően malignitás esetén az összesített túlélés $57 \%$ (31/54).

A transzplantációval összefüggő halálozás alacsony volt a +30. nap után a teljes betegcsoportban (9/100, 9\%). A relapszushoz kötődő halálozások 47\%-ában (8/17) a recidíva előtt semilyen más korai transzplantációs szövődmény nem jelentkezett. Nem volt különbség a TATMA-s és nem TA-TMA-s (15/20 (75\%) vs. 59/80 $(74 \%) ; p=0,90)$ betegek összesített túlélési eredményei között.

A historikus betegcsoporttal összehasonlítva, az öszszesített túlélés a transzplantációs technika fejlődésével párhuzamosan javult (74/100 (74\%) vs. 23/54 (43\%); $p=0,0001)$. A transzplantációhoz kötődő halálozás jelentősen magasabb volt a historikus betegcsoportban $(9 / 100(9 \%)$ vs. $22 / 54(41 \%) ; p<0,00001)$, míg a relapszushoz kötődő halálozásban nem volt különbség a két betegcsoport között $(17 / 54(31 \%)$ vs. $9 / 31$ (29\%); $p=$ $0,81)$.

\section{Diszkusszió}

Prospektív, konszekutív kohorszvizsgálatunk keretében elsőként vizsgáltuk a transzplantációs szövődmények egymáshoz viszonyított előfordulását a csökentett toxicitású treosulfan alapú kondícionáló kezelés bevezetése óta. A Dél-pesti Centrumkórházban (korábbi nevén Szent László Kórházban) 1992 óta végzünk allogén őssejtátültetést gyermek betegek esetében. A malignus betegségekben végzett transzplantációkon túl központunk hazai viszonylatban egyedülálló tapasztalattal rendelkezik a nem malignus betegségek esetén végzett őssejt-transzplantáció terén is.

Korábban a tx-hez alkalmazott kondícionáló kezelések sikere a dózisintenzitáson alapult, azonban a jelentős toxicitás miatt a korai szövődmények rátája magas volt [16]. 
Az elmúlt időszakban azonban a gyermekkori transzplantációk kondícionáló kezelésében is paradigmaváltás történt. Míg kezdetben fóként teljestest besugárzást vagy busulphan alapú kondícionáló kezelést alkalmaztak, a fiatal életkort szem előtt tartva, illetve az életminőség javítása céljából gyermekkorban is előtérbe kerültek a csökkentett toxicitású, treosulfan alapú valamint a csökkentett intenzitású előkészítő kezelések, ahol nagyobb szerep juthat a graft-versus-tumor effektusnak [17-19]. A treosulfan alapú kondícionáló kezelés kedvezőbb toxicitási profilja miatt alacsonyabb a korai szövődmények, így a GVHD előfordulási gyakorisága is [20]. Közleményünkben a követett betegcsoport adatait elemezve elsőként tekintjük át a tx utáni szövődmények előfordulását prospektív módon az újabb kondícionáló kezelések bevezetése óta.

A gyerekek kétharmadánál észleltünk korai szövődményt, ami egybeesik az irodalmi adatokkal [21]. A döntôen csökkentett toxicitású kondícionáló kezelések után az akut GVHD incidenciája alacsony (26\%) volt. Ez összevethető a treosulfan alapú kondícionáló kezelés kapcsán észlelt szövődményadatokkal [22-24], és jelentősen alacsonyabb a hagyományos kondícionáló kezelést kapó felnőttek körében tapasztalt incidenciához képest [25]. A csökkentett toxicitásnak megfelelöen alacsony (7\%) a súlyos GVHD előfordulása, és a transzplantációhoz kötődő halálozás $(9 \%)$ is $[18,22,26]$.

A TA-TMA incidenciáját az újonnan definiált TA-TMA kritériumok alkalmazása mellett nehéz összevetni az irodalmi adatokkal, mivel azok értékét (8-20\%) az alkalmazott kritériumrendszer befolyásolja. Eredményeink azonban a Jodele és mtsai által publikáltakkal jól összemérhetóek, mert az új diagnosztikus kritériumokat a fenti munkacsoport gyermekbetegek körében írta le [11]. A TA-TMA incidenciája és a szervkárosodással járó súlyos esetek száma alacsonyabb volt, mint az Jodele és mtsai kimutatták [11]. Az amerikai protokollban (Children's Oncology Group, COG) a vizsgálati periódus alatt is teljestest-besugárzást alkalmaztak kondícionáló kezelésként, így ennek toxicitása magyarázhatja a későbbi magasabb TA-TMA incidenciát [11]. A klinikai megjelenés hasonlóságain túl a GVHD-t és a TA-TMA-t kiváltó tényezők egy része is megegyezik [27]. Emellett, mint azt saját betegcsoportunkban is megfigyeltük - a két klinikai entitás gyakran együttesen fordul elő. A TA-TMA a másik két korai szövődmény jelentkezését követően lépett fel, így TA-TMA fennállását döntően olyan betegeknél definiáltuk csak, akiknél GVHD és/vagy vírusreaktiváció is fennállt. A vizsgálatunk során diagnosztizált TA-TMA-s esetek döntően enyhe formában zajlottak, és az immunszuppresszív terápia módosítása vagy leállítása után oldódtak. Minden TA-TMA-s epizód ciclosporin alapú immunszuppresszív terápia kapcsán jelentkezett. Az immunszuppresszív terápia gyógyszerei a TA-TMA triggerei lehetnek [28], de még kevés információ áll rendelkezésünkre a különböző immunszuppresszív szerek és a TA-TMA kapcsolatáról.
A súlyos szövődmények alacsony számát magyarázhatja, hogy a gyermekhematológiában a hosszú távú kedvezőtlen hatások elkerülése végett [29] egyre inkább elötérbe kerültek a csökkentett toxicitású kezelések [19]. Bár a transzplantációval összefüggő halálozás alacsony, a halálozás fő oka malignus betegségek esetén a relapszus [30]. Betegcsoportunkban a relapszusráta a környező országokéhoz hasonló, $41 \%$. A legtöbb visszaesés a transzplantáció utáni első évben detektálható [30]. Ebben a tekintetben nem volt különség a treosulfan és busulphan alapú kondícionáló kezelést kapó csoportok között. A vizsgálati időszak lezárultát követően a magas relapszusráta miatt újabb paradigmaváltásra volt szükség az akut lymphoblasztos leukémiás gyerekek allogén transzplantációjának kondícionáló kezelésében, így a teljestest besugárzás újra a kondícionáló kezelés része lett.

\section{Konklúzió}

A csökkentett toxicitású kondícionáló kezelések bevezetése óta a súlyos korai transzplantációs szövődmények száma és a transzplantációhoz kötődő halálozás alacsony. A TA-TMA döntően enyhe formában, kizárólag ciclosporin adása során, más transzplantációs szövődményekhez társultan jelentkezett. A nem malignus betegségben szenvedők összesített túlélése kiváló, azonban a malignitás miatt transzplantáltak relapszus rátája magas. A teljestest-besugárzás újbóli alkalmazása a gyermekbetegek kezelésében a korai szövődmények előfordulását megváltoztathatja majd, ezért további longitudinális követéses vizsgálatok szükségesek a transzplantáció után a TA-TMA és a többi korai szövődmény egymáshoz viszonyított elöfordulásának felmérésére. Emellett nagy esetszámú követéses vizsgálatok szervezése indokolt az immunszuppresszív szerek és a transzplantációs szövődmények TATMA patomechanizmusában betöltött szerepének vizsgálatára.

\section{Köszönetnyilvánítás}

A szerzők köszönetüket fejezik ki a betegellátásban részt vevő nővéreknek és a laboratóriumi dolgozóknak.

Nyilatkozat: A közlemény korábban más folyóiratban nem jelent meg, és más folyóirathoz beküldésre nem került. A levelező szerző elolvasta a Szerzői Útmutató instrukcióit. Érdekeltségek: A szerzőknek nincsenek érdekeltségeik. Anyagi támogatás: Az első szerző a Magyar Hematológiai és Transzfuziológiai Társaság Fiatal Kutatói Ösztöndíjának támogatásával végezte a kutatásokat.

Szerzői munkamegosztás: A kéziratot a levelező szerző írta.

\section{Irodalom}

[1] Laberko A, Gennery AR. Clinical considerations in the hematopoietic stem cell transplant management of primary immunodeficiencies. Expert Rev Clin Immunol. 2018; 14: 297-306. 
[2] Locatelli F, Strahm B. How I treat myelodysplastic syndromes of childhood. Blood 2018; 131: 1406-1414.

[3] Okamoto S. Current indication for hematopoietic cell transplantation in adults. Hematol Oncol Stem Cell Ther. 2017; 10: 178183.

[4] Singh AK, McGuirk JP. Allogeneic Stem Cell Transplantation: A Historical and Scientific Overview. Cancer Res. 2016; 76: 64456451.

[5] Düver F, Weißbrich B, Eyrich M, Wölfl M, Schlegel PG, Wiegering V. Viral reactivations following hematopoietic stem cell transplantation in pediatric patients - A single center 11-year analysis. PLoS One 2020; 15: e228451. published online.

[6] Jagasia M, Arora M, Flowers ME, et al. Risk factors for acute GVHD and survival after hematopoietic cell transplantation. Blood 2012; 119: 296-307.

[7] Obut F, Kasinath V, Abdi R. Post-bone marrow transplant thrombotic microangiopathy. Bone Marrow Transplant. 2016; 51: 891897.

[8] Ruutu T, Barosi G, Benjamin RJ, et al. Diagnostic criteria for hematopoietic stem cell transplant-associated microangiopathy: results of a consensus process by an International Working Group. Haematologica 2007; 92: 95-100.

[9] Ho VT, Cutler C, Carter S, et al. Blood and marrow transplant clinical trials network toxicity committee consensus summary: thrombotic microangiopathy after hematopoietic stem cell transplantation. Biol Blood Marrow Transplant. 2005; 11: 571-575.

[10] Cho BS, Yahng SA, Lee SE, et al. Validation of recently proposed consensus criteria for thrombotic microangiopathy after allogeneic hematopoietic stem-cell transplantation. Transplantation 2010; 90: 918-926.

[11] Jodele S, Dandoy CE, Myers KC, et al. New approaches in the diagnosis, pathophysiology, and treatment of pediatric hematopoietic stem cell transplantation-associated thrombotic microangiopathy. Transfus Apher Sci. 2016; 54: 181-190.

[12] Horváth O, Kállay K, Csuka D, et al. Early increase in complement terminal pathway activation marker $\mathrm{sC} 5 \mathrm{~b}-9$ is predictive for the development of thrombotic microangiopathy after stem cell transplantation. Biol Blood Marrow Transplant. 2018; 24: 989996.

[13] Lawitschka A, Lucchini G, Strahm B, et al. Pediatric acute graftversus-host disease prophylaxis and treatment: surveyed real-life approach reveals dissimilarities compared to published recommendations. Transpl Int. 2020; 10.1111. published online.

[14] Glucksberg H, Storb R, Fefer A, et al. Clinical manifestations of graft-versus-host disease in human recipients of marrow from HL-A-matched sibling donors. Transplantation 1974; 18: 295304.

[15] García-Martín P, Alarcón-Payer C, López-Fernández E, et al. Transplantation-associated thrombotic microangiopathy in patients treated with sirolimus and cyclosporine as salvage therapy for graft-versus-host disease. Ann Pharmacother. 2015; 49: 986994.

[16] Gyurkocza B, Sandmaier BM. Conditioning regimens for hematopoietic cell transplantation: one size does not fit all. Blood 2014; 124: 344-353.

[17] Slatter MA, Boztug H, Pötschger U, et al. Treosulfan-based conditioning regimens for allogeneic haematopoietic stem cell trans- plantation in children with non-malignant diseases. Bone Marrow Transplant. 2015; 50: 1536-1541.

[18] Boztug H, Sykora KW, Slatter M, et al. European Society for Blood and Marrow Transplantation analysis of treosulfan conditioning before hematopoietic stem cell transplantation in children and adolescents with hematological malignancies. Pediatr Blood Cancer. 2016; 63:139-148.

[19] Willasch AM, Peters C, Sedláček P, et al. Myeloablative conditioning for allo-HSCT in pediatric ALL: FTBI or chemotherapy? - A multicenter EBMT-PDWP study. Bone Marrow Transplant. 2020; published online

[20] Slatter MA, Rao K, Amrolia P, et al. Treosulfan-based conditioning regimens for hematopoietic stem cell transplantation in children with primary immunodeficiency: United Kingdom experience. Blood 2011; 117: 4367-4375.

[21] Hierlmeier S, Eyrich M, Wölfl M, Schlegel PG, Wiegering V. Early and late complications following hematopoietic stem cell transplantation in pediatric patients - A retrospective analysis over 11 years. PLoS One 2018; 13: e0204914.

[22] Slatter MA, Rao K, Abd Hamid IJ, et al. Treosulfan and fludarabine conditioning for hematopoietic stem cell transplantation in children with primary immunodeficiency: UK experience. Biol Blood Marrow Transplant. 2018; 24: 529-536.

[23] Nemecek ER, Hilger RA, Adams A, et al. Treosulfan, fludarabine, and low-dose total body irradiation for children and young adults with acute myeloid leukemia or myelodysplastic syndrome undergoing allogeneic hematopoietic cell transplantation: Prospective phase II trial of the Pediatric Blood and Marrow Transplant Consortium. Biol Blood Marrow Transplant. 2018; 24: 16511656.

[24] Casper J, Holowiecki J, Trenschel R, et al. Allogeneic hematopoietic SCT in patients with AML following treosulfan/fludarabine conditioning. Bone Marrow Transplant. 2012; 47: 11711177.

[25] Nassereddine S, Rafei H, Elbahesh E, Tabbara I. Acute graft versus host disease: A comprehensive review. Anticancer Res. 2017; 37: 1547-1555.

[26] Kröger N, Bornhäuser M, Stelljes M, et al. Allogeneic stem cell transplantation after conditioning with treosulfan, etoposide and cyclophosphamide for patients with ALL: a phase II-study on behalf of the German Cooperative Transplant Study Group and ALL Study Group (GMALL). Bone Marrow Transplant. 2015; 50: 1503-1507.

[27] Laskin BL, Goebel J, Davies SM, Jodele S. Small vessels, big trouble in the kidneys and beyond: hematopoietic stem cell transplantation-associated thrombotic microangiopathy. Blood 2011; 118: $1452-1462$.

[28] Elfeky R, Lucchini G, Lum SH, et al. New insights into risk factors for transplant-associated thrombotic microangiopathy in pediatric HSCT. Blood Adv. 2020; 4: 2418-2429.

[29] Lawitschka A, Peters C. Long-term effects of myeloablative allogeneic hematopoietic stem cell transplantation in pediatric patients with acute lymphoblastic leukemia. Curr Oncol Rep. 2018; 20: 74 .

[30] Kuhlen M, Willasch AM, Dalle JH, et al. Outcome of relapse after allogeneic HSCT in children with ALL enrolled in the ALL-SCT 2003/2007 trial. Br J Haematol. 2018; 180: 82-89.

A cikk a Creative Commons Attribution 4.0 International License (https://creativecommons.org/licenses/by/4.0/) feltételei szerint publikált Open Access közlemény, melynek szellemében a cikk bármilyen médiumban szabadon felhasználható, megosztható és újraközölhető, feltéve, hogy az eredeti szerző és a közlés helye, illetve a CC License linkje és az esetlegesen végrehajtott módosítások feltüntetésre kerülnek. (SID_1) 